\title{
22. MOLECULAR STRATIGRAPHIC STUDY OF SEDIMENTS FROM HOLES 658A AND 660A, LEG 108 1
}

\author{
J. G. Poynter, ${ }^{2}$ P. Farrimond, ${ }^{2}$ S. C. Brassell, ${ }^{2,3}$ and G. Eglinton ${ }^{2}$
}

\begin{abstract}
The solvent-extractable organic fractions of a series of sediment samples that were taken at specific intervals from Holes 658A and 660A on Ocean Drilling Program Leg 108 were quantitatively analyzed in terms of their molecular composition. The resulting multivariate time series show how the composition and concentration of this organic component is linked to the paleoenvironmental and paleoclimatic histories of the two sites.
\end{abstract}

\section{INTRODUCTION}

The distribution and composition of a series of molecular biomarkers (originally termed "chemical fossils"; Eglinton and Calvin, 1967) have been determined in parts of Holes $658 \mathrm{~A}$ and $660 \mathrm{~A}$. This type of molecular stratigraphic approach has previously been demonstrated to be a useful tool in assessing the paleoenvironmental history of successive horizons in a sediment core (Brassell et al., 1986a).

To be of optimum use in a molecular stratigraphic study, a biological marker compound should have a known and restricted distribution in the biosphere, be sufficiently inert to survive transportation and incorporation into a sediment, and once in situ should remain in a recognizable and quantifiable form. In this study we trace the downhole abundances of selected biomarkers from four specific groups of organisms, namely: (1) $n$-alkanes $\left(\mathrm{C}_{2 \tau}-\mathrm{C}_{35}\right)$ and $n$-alkanols $\left(\mathrm{C}_{22}-\mathrm{C}_{32}\right)$ from the epicuticular waxes of higher plants (Eglinton et al., 1962; Eglinton and Hamilton, 1963; Kolattukudy, 1976); (2) alkan1,15-diols $\left(\mathrm{C}_{28}-\mathrm{C}_{32}\right)$ of possible cyanobacterial origin (Morris and Brassell, 1988); (3) dinosterol from dinoflagellates (Boon et al., 1979); and (4) long-chain unsaturated alkenones $\left(\mathrm{C}_{3 T}-\mathrm{C}_{39}\right)$ from Prymnesiophyte algae (Volkman et al., 1980; Marlowe et al., 1984).

The lipid signature derived from these organisms and subsequently preserved in the sedimentary record is related to the environmental conditions at the time of deposition. We can also obtain information about the marine primary productivity and the eolian supply of land plant debris, features having a strong link with prevailing climatic conditions. Furthermore, it has recently been shown that the degree of unsaturation of the long-chain alkenones in a sediment core taken from the northeast Atlantic records the glacial/interglacial cycles over at least the last 500 k.y. (Brassell et al., 1986b). An analysis of the lipid distributions of these compounds in the Prymnesiophyte alga Emiliania huxleyi grown at $8^{\circ}, 10^{\circ}, 15^{\circ}, 20^{\circ}$, and $25^{\circ} \mathrm{C}$ has shown a linear relationship between the $\mathrm{U}_{37}^{\mathrm{k}}$ index (measuring the degree of unsaturation) and the growth temperature (Marlowe, 1984; confirmed and extended by Prahl and Wakeham, 1987). The rationale for-

\footnotetext{
${ }^{1}$ Ruddiman, W., Sarnthein, M., et al., 1989. Proc. ODP, Sci. Results, 108: College Station, TX (Ocean Drilling Program).

2 Organic Geochemistry Unit, School of Chemistry, University of Bristol, Cantock's Close, Bristol BS8 1TS, United Kingdom (present address: Organic Geochemistry Unit, University of Newcastle, Newcastle, United Kingdom).

${ }^{3}$ Present address: Department of Geology. School of Earth Sciences, Stanford University, Stanford, CA 94305.
}

warded to support this observation suggests that Prymnesiophyte algae biosynthesize di-, tri-, and tetra-unsaturated alkenones in varying amounts to maintain their cell membrane fluidity during changes in their growth temperature (Brassell et al., 1986a).

Two holes are addressed in the present study. Hole $660 \mathrm{~A}$ lies in deep water $(4327 \mathrm{~m})$ on the lower slope of the rise that forms an extension of the Sierra Leone Rise toward the northeast. The organic input to this site derives from the overlying photic zone and through an eolian input largely from the African Sahel Zone. Marine productivity in this region is controlled by the Guinea Dome Upwelling (an eastern extension of the North Equatorial Divergence Zone), which maximizes during the Northern Hemisphere summer. The eolian input to this site maximizes during the Northern Hemisphere winter since it is dependent upon the intensity of atmospheric circulation and continental aridity (Sarnthein et al., 1981). Extensive transportation of terrestrial-derived organic matter to the site via density currents is unlikely due to the position of the hole on a rise and its proximity to the continental shelf.

Hole $658 \mathrm{~A}$ is located $160 \mathrm{~km}$ west of Cap Blanc in water depths of $2263.6 \mathrm{~m}$. The site was drilled into a largely undisturbed pillow-shaped sediment section near the outer margin of a protruding terrace on the continental slope (Ruddiman, Sarnthein, et al., 1988), a position that should restrict the lateral transport of sediment to the site via near-bottom density flow. The site lies directly beneath one of the major nearshore cells of permanent oceanic upwelling and also receives a significant supply of eolian material (Simoneit and Eglinton, 1977; Simoneit et al., 1977) from the northern trade winds that control upwelling intensity.

\section{METHODS}

\section{Extraction procedure}

Free organic matter was isolated from wet sediments through a series of extractions (each $15 \mathrm{~min}$ ) in a sonic tank. The first extraction used methanol to facilitate the removal of lipids from a largely aqueous sample. The resulting liquid fraction, largely consisting of water and methanol, was decanted off the sediment following centrifugation of the sample. The extraction procedure was repeated using progressively less polar solvents. Each sample was extracted five times: twice with methanol, once with methanol/dichloromethane (1:1), and finally twice with dichloromethane.

The purpose of these successive extractions was to maintain the inorganic sediment fraction in a single liquid phase where the polarity was systematically reduced to allow the hydrophobic components of the samples to be incorporated into the liquid phase. Quantitative tests (unpubl. results) reveal an extraction efficiency of $\sim 95 \%$ using this five-step extraction procedure. After the second methanol extrac- 

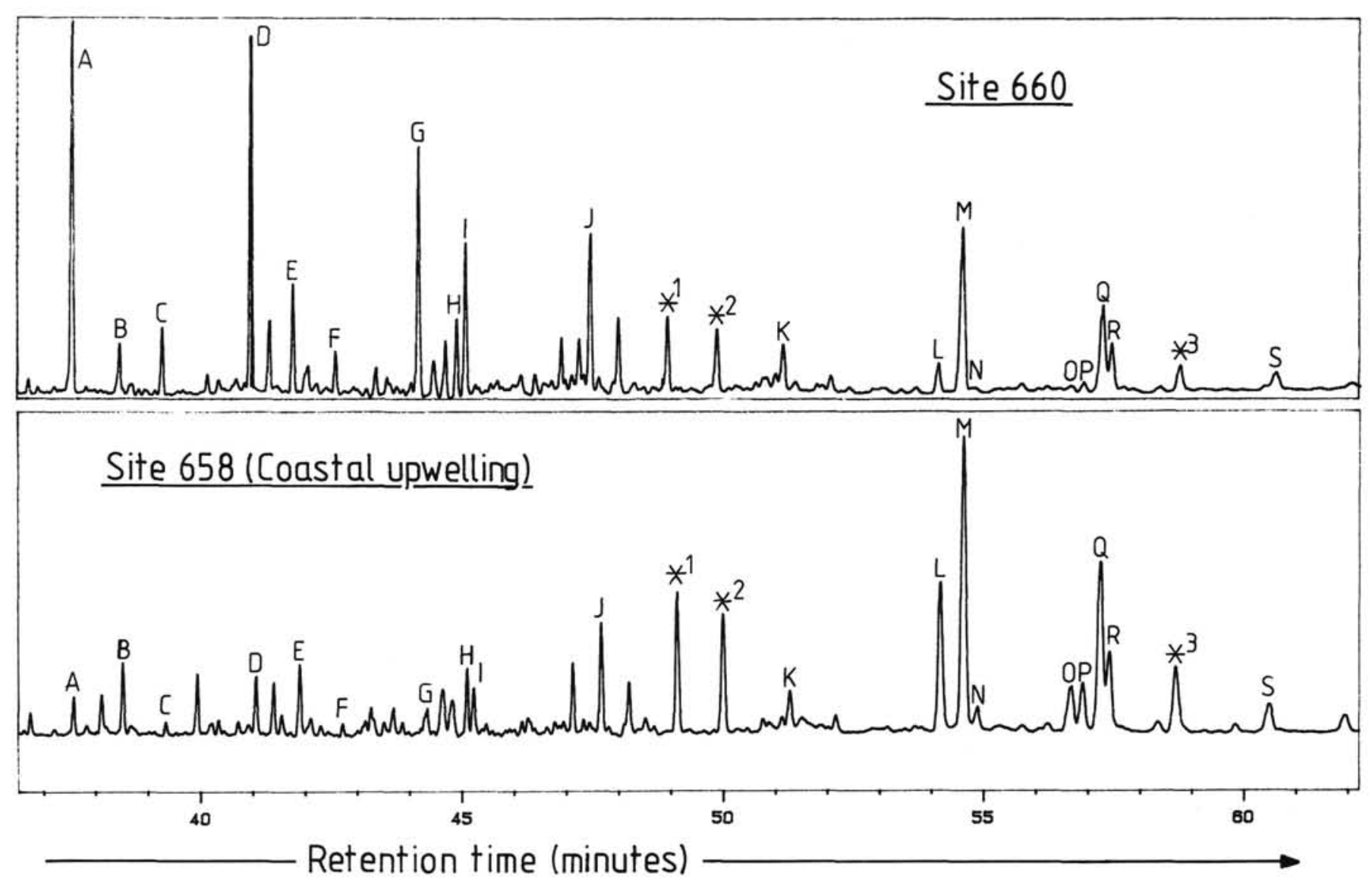

Figure 1. Gas chromatograms comparing the lipid distributions of two Leg 108 sediment samples. The sample from Site 660 contains a greater relative proportion of terrestrial-derived components ( $n$-alkanes and $n$-alkanols), while the Site 658 sample is dominated by marine-derived compounds (e.g., alkenones and alkan-1,15-diols). Compound assignments: $\mathrm{A}=\mathrm{C}_{29} n$-alkane; $\mathrm{B}=\mathrm{C}_{26} n$-alkanol; $\mathrm{C}=\mathrm{C}_{30} n$-alkane; $\mathrm{D}=\mathrm{C}_{31}$ $n$-alkane; $\mathrm{E}=\mathrm{C}_{28} n$-alkanol; $\mathrm{F}=\mathrm{C}_{32} n$-alkane; $\mathrm{G}=\mathrm{C}_{33} n$-alkane; $\mathrm{H}=\mathrm{C}_{30} n$-alkanol; $\mathrm{I}=4 \alpha, 23,24$-trimethyl-5 $\alpha(\mathrm{H})$-cholest-22-en- $3 \beta$-ol (dinosterol); $\mathrm{J}=\mathrm{C}_{30}$ alkan-1,15-diol; ${ }^{*} 1=\mathrm{C}_{36} \quad n$-alkane (internal standard); $* 2=$ cholesteryl hexanoate (internal standard); $\mathrm{K}=\mathrm{C}_{32}$ alkan-1,15-diol; $\mathrm{L}=\mathrm{C} 37: 3 \mathrm{Me}$ alkenone; $\mathrm{M}=\mathrm{C} 37: 2 \mathrm{Me}$ alkenone; $\mathrm{N}=\mathrm{C} 37: 2 \mathrm{Me}$ ester; $\mathrm{O}=\mathrm{C} 38: 3 \mathrm{Et}$ alkenone; $\mathrm{P}=\mathrm{C} 38: 3 \mathrm{Me}$ alkenone; $\mathrm{Q}=$ C38:2Et alkenone; $\mathrm{R}=\mathrm{C} 38: 2 \mathrm{Me}$ alkenone; ${ }^{*} 3=\mathrm{C}_{40} n$-alkane (internal standard); $\mathrm{S}=\mathrm{C} 39: 2 \mathrm{Et}$ alkenone.

tion, a known quantity of three internal standards was added $\left(\mathrm{C}_{36}\right.$ and $\mathrm{C}_{40} n$-alkanes and cholesteryl hexanoate); these compounds were recovered in the extractable organic fraction of the sediment. Subsequent quantitation was performed relative to two of these compounds.

The combined extracts were washed with aqueous potassium chloride to separate salts and water, and the organic layer was removed. The remaining aqueous layer was extracted twice with dichloromethane to recover the hydrophobic biological markers. These organic extracts were combined, and any excess solvent was removed by rotary evaporation before being stored dry in vials at $4^{\circ} \mathrm{C}$. This method was developed from the one used by Bligh and Dyer (1959).

It was found during this study that as little as $0.5 \mathrm{~g}$ of sediment from Hole $658 \mathrm{~A}$ and $1.0 \mathrm{~g}$ from Hole $660 \mathrm{~A}$ could be used to determine a good lipid signature. However, it must be noted that with such small sample sizes the problem arises as to whether the subsample truly represents an average composition of the parent sediment horizon (i.e., sediment inhomogeneity).

\section{Sample preparation}

Traditionally, organic geochemists fractionate lipid extracts into compound classes (or polarity fractions) prior to analysis. However, in order to maintain the speed and efficiency of the procedure, and also to avoid the introduction of additional sources of variance, the samples were analyzed as total lipid extracts. Derivation with commercial grade bis-trimethylsilyl-trifluoroacetamide was necessary prior to gas chromatography analysis.

\section{Analysis and Quantitation}

Total organic extracts were analyzed by capillary gas chromatography (GC) using a Carlo Erba Mega Series 5300 instrument equipped with a Hewlett-Packard HP-1 column (cross-linked methylsilicone; $50-\mathrm{m} \times 0.32-\mathrm{mm}$ inner diameter). Hydrogen was used as the carrier gas with a flow rate of $50 \mathrm{~cm} / \mathrm{s}$. The oven's temperature was $50^{\circ} \mathrm{C}$ for $1 \mathrm{~min}, 50^{\circ}-150^{\circ} \mathrm{C}$ at $15^{\circ} \mathrm{C} / \mathrm{min}, 150^{\circ}-300^{\circ} \mathrm{C}$ at $4^{\circ} \mathrm{C} / \mathrm{min}$, and $30 \mathrm{~min}$ at isothermal.

Individual components of the lipid extracts were quantified by comparing manually determined peak areas, calculated from data acquired on a VG Minichrom data system, with internal standards added during the extraction procedure. Subsequent calculations and data processing were carried out on an IBM AT using Lotus 1-2-3 software and on a VAX 11/50 running under VMS 4.4 using Statistical Analysis System (SAS) princomp procedure.

\section{RESULTS}

The components labeled in the GC traces shown (Fig. 1) are representatives of the biomarker series listed in the "Introduction." They do not include every homologue or every known marker derived from their biological sources. In particular, abundances of representatives of the higher plant $n$-alkanols and $n$-alkanes are reported, but abundances of their $n$-fatty acid counterparts are not. This is because our analysis method does not include acidification, so partial loss of fatty 


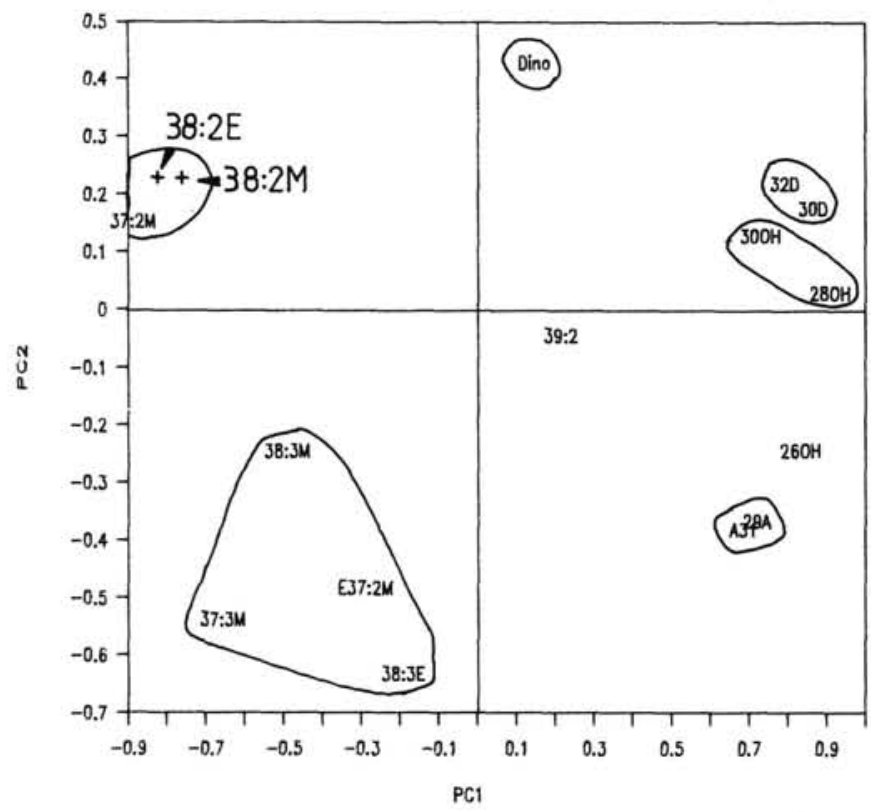

Site 658

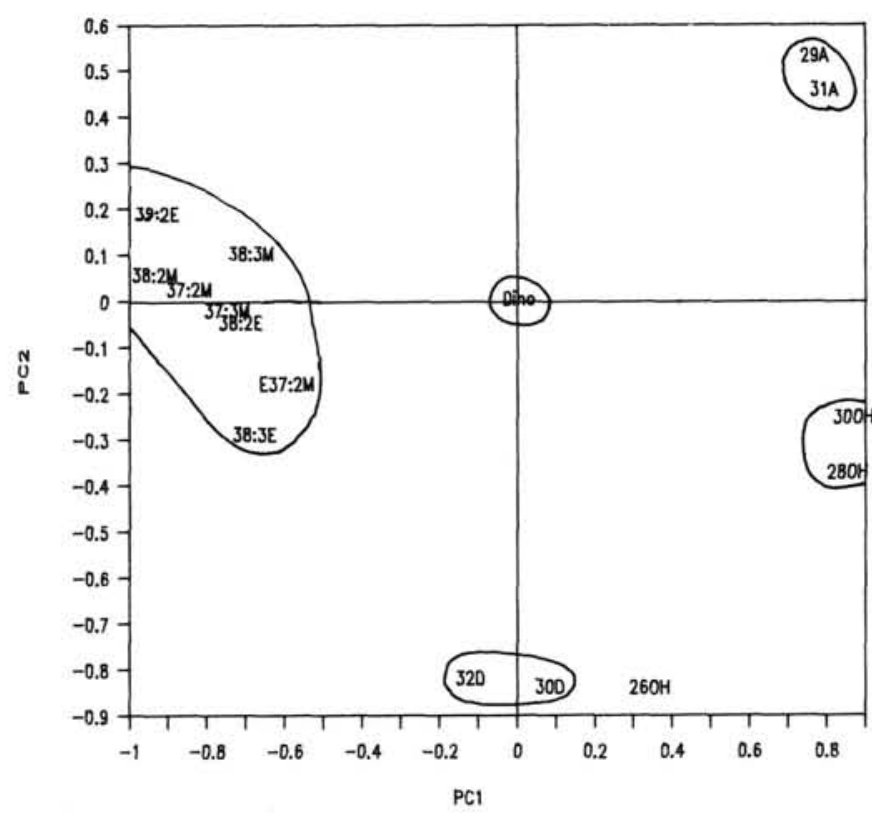

Site 660

Figure 2. The loadings plots ( $\mathrm{PC} 1$ vs. $\mathrm{PC} 2$ ) for Sites 658 and 660 . The raw data comprised the abundances for each sediment sample of the following: the $\mathrm{C}_{29}$ and $\mathrm{C}_{31}$-alkanes; the $\mathrm{C}_{26}, \mathrm{C}_{28}$, and $\mathrm{C}_{30}$ n-alkanols; the $\mathrm{C}_{30}$ and $\mathrm{C}_{32}$ alkan-1,15-diols; dinosterol; the C37:3Me, C37:2Me, $\mathrm{C} 38: 3 \mathrm{Et}, \mathrm{C} 38: 3 \mathrm{Me}, \mathrm{C} 38: 2 \mathrm{Et}, \mathrm{C} 38: 2 \mathrm{Me}$, and C39:2Et alkenones; and the C37:2Me ester. The data were scaled prior to analysis by standardizing the downhole variance of each compound and normalizing the sum of all the lipids in each sample to a constant total.

acid salts would be expected. Nevertheless, the presence of fatty acids was noted during GC-MS analysis of selected free lipid extracts, and their concentration appeared to decrease downhole, consistent with the notion that they are degraded or incorporated into the bound organic fraction.

While we accept that much information useful in paleoclimatic reconstructions can be contained in the component distributions within specific compound classes (e.g., Brassell et al., 1980; Poynter et al., 1989), the intention of the present study is to address a large number of sediment samples while keeping experimental error to a minimum. Consequently, only abundances of those compounds that could be quantitatively determined in every sample are considered in this paper. These comprise the following: the $\mathrm{C}_{26}, \mathrm{C}_{28}$, and $\mathrm{C}_{30} n$-alkanols and the $\mathrm{C}_{29}$ and $\mathrm{C}_{31}$ n-alkanes; the $\mathrm{C}_{30}$ and $\mathrm{C}_{32}$ alkan-1,15-diols; the C37:3Me, C37:2Me, C38:3Et, C38:3Me, C38:2Et, C38: $2 \mathrm{Me}$, and $\mathrm{C} 39: 2 \mathrm{Et}$ alkenones; the $\mathrm{C} 37: 2 \mathrm{Me}$ ester; and dinosterol.

\section{Data Reduction}

In the present study, we used principal components analysis (PCA) to reduce the data set by identifying and summing those components that covaried. Loadings plots from PCAs of a similar data set have been used previously to demonstrate how the individual components of a series of biomarkers covary downhole (Brassell et al., 1986a). One advantage of PCA is that the approach reveals correlations between variables without "eyeballing" peaks and troughs in downhole lipid profiles. Here, the loadings plots of the variables on the first and second principal components are shown for Holes $658 \mathrm{~A}$ and $660 \mathrm{~A}$ (Fig. 2). The raw data were scaled prior to analysis by standardizing each variable to unit variance and normalizing the sum of each sample's determined biomarker abundance to a constant total (Davis, 1973).
On the basis of the PCAs (Fig. 2) and chemical knowledge, the following compound "groups" or "sums" were used in representing specific biological contributions (discussed in the "Introduction"):

1. $\mathrm{C}_{29}$ and $\mathrm{C}_{31} n$-alkanes (higher plant epicuticular waxes);

2. $\mathrm{C}_{28}$ and $\mathrm{C}_{30} n$-alkanols (higher plant epicuticular waxes);

3. $\mathrm{C}_{30}$ and $\mathrm{C}_{32}$ alkan-1,15-diols (cyanobacteria?);

4. C37:2Me, C38:2Me, and C38:2Et alkenones (Prymnesiophyte algae);

5. C37:3Me, C38:3Et, and the C37:2 methyl ester (Prymnesiophyte algae); and

6. Dinosterol (dinoflagellates).

The $\mathrm{C}_{26} n$-alkanol was excluded from the data set since it did not plot with the other higher plant alkanols (Fig. 2), probably due to undetected co-elution problems and/or significant quantitation error owing to low concentration. The C39:2Et alkenone was also excluded because it plotted away from all other alkenones in Hole 658A; again, this was probably due to poor quantitation owing to low abundance. In the loadings plot for Hole $658 \mathrm{~A}$, the remaining alkenones were split into two groups, one containing the di- and the other the tri-unsaturated alkenones. However, this feature was not observed on the loadings plot for Hole $660 \mathrm{~A}$. A contributing factor to this must be the larger difference between the mean interglacial and glacial sea-surface water temperatures (glacial/interglacial temperature anomaly) at Hole $658 \mathrm{~A}$ (ca. $6^{\circ} \mathrm{C}$ ) compared with Hole $660 \mathrm{~A}$ (ca. $2^{\circ} \mathrm{C}$ ), as shown in Figure 3 (McIntyre et al., 1976).

The downhole profiles of these biomarker sums together with the $\mathrm{U}_{37}^{\mathrm{k}}$ index are shown plotted against age for Hole 658A (Fig. 4); the chronology used was provided by Sarnthein and Tiedemann (this vol.). The same information is plotted against depth for Hole $660 \mathrm{~A}$ (Fig. 5). The $\mathrm{U}_{37}^{\mathrm{k}}$ index was determined using Eq. 1: 


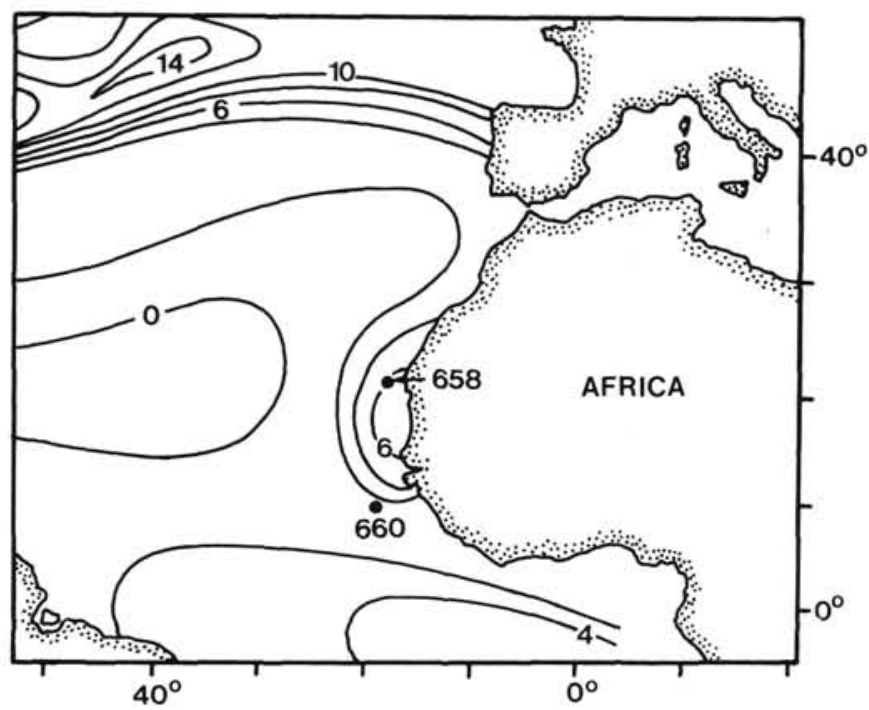

Figure 3. A map of the eastern Atlantic Ocean displaying the August glacial/interglacial anomaly contours $\left({ }^{\circ} \mathrm{C}\right.$ ) (modified from McIntyre et al., 1976). The positions of Sites 658 and 660 are shown.

$$
\mathrm{U}_{37}^{\mathrm{k}}=(\mathrm{C} 37: 2 \mathrm{Me}) /[(\mathrm{C} 37: 2 \mathrm{Me})+(\mathrm{C} 37: 3 \mathrm{Me})],
$$

where $\mathrm{C} x: y \mathrm{Me}$ denotes the $\mathrm{C} x$ methyl alkenone with $y$ double bonds. The full structure of the alkenones isolated from sediments has recently been explained by Rechka and Maxwell (1988). The $C_{37}$ tetra-unsaturated alkenone was not included in this formula since it was generally absent from the sediments in this study. Although it was present in quantifiable amounts in the upper parts of Hole 658A (ca. 0-24 k.y.), its concentration relative to the di- and tri-unsaturated alkenones decreased rapidly to zero downhole. This observation is in contrast with the predicted rise that would be associated with a sediment deposited during ice age stage two and suggests loss of the tetra-unsaturated alkenone through microbial degradation during early diagenesis.

\section{DISCUSSION}

\section{Comparison of the $U_{37}^{k}$ Profile of Hole $658 \mathrm{~A}$ with a Stacked $\delta^{18} \mathbf{O}$ Record}

The close similarity between a plot of the $U_{37}^{k}$ index of Hole $658 \mathrm{~A}$ and the stacked oxygen isotope record of five lowlatitude deep-sea cores (Fig. 6) taken from Imbrie et al. (1984) confirms the hypothesis of Brassell et al. (1986b) that the degree of unsaturation of long-chain alkenones recovered from sediments monitors climatic change. However, in order to describe the features of the alkenone unsaturation profile, we should devise a standard nomenclature for the events within it. Toward this end we consider the following points:

1. The $U_{37}^{k}$ record is thought to be dominated by the effect of sea-surface water temperature. Thus, we should not expect events within it to be strictly synchronous with those of the $\delta^{18} \mathrm{O}$ record, which includes a large ice-volume signal (e.g., Dansgaard and Tauber, 1969). Consequently, we cannot simply apply the nomenclature of oxygen isotope stratigraphy.

2. Sea-surface water temperature is a local phenomenon. Thus, $\delta^{18} \mathrm{O}$ measures a predominantly global climatic signal, and the $U_{37}^{k}$ index is dominated by local temperature conditions.

Nevertheless, in those parts of the Atlantic that show appreciable differences between average glacial and interglacial temperatures (particularly upwelling areas), we expect the
$\mathrm{U}_{37}^{\mathrm{k}}$ and $\delta^{18} \mathrm{O}$ curves to show many features in common. Hence, we propose basing $U_{37}^{k}$ events upon the nomenclature used by Prell et al. (1986) for $\delta^{18} \mathrm{O}$ events. Major glacial stages are given even numbers, and interglacials, odd numbers; recent events are given low numbers, and older events, high numbers. Minor events within a stage are also numbered (glacials are given even numbers; interglacials, odd numbers) in the same way. The major and minor numbered events are separated by a decimal point. However, in order to distinguish the events in the $U_{37}^{k}$ profiles, the numbers are preceded by the letter K (ketone).

At Hole $658 \mathrm{~A}$, the section of the $U_{37}^{k}$ curve spanning the last $24 \mathrm{k} . \mathrm{y}$. includes events K1.1 and K2.2 (Fig. 6). This part of the section was sampled and analyzed at 800 -yr intervals in order to investigate the molecular stratigraphic changes that occur during the cessation of a major ice age. A full discussion of the $U_{37}^{k}$ signal and the associated response of the other biomarkers will be reported after the acquisition of further data. However, the $U_{37}^{k}$ profile does appear to show the two-step deglaciation recognized by Berger et al. (1985).

The $U_{37}^{k}$ curve broadly parallels the stacked $\delta^{18} \mathrm{O}$ curve (Fig. 6), although many of the more short-lived events appear to have a higher amplitude in the former (i.e., K5.4, K7.4, $\mathrm{K} 8.6$, and $\mathrm{K} 12.4$ ). This is not unexpected since the $\delta^{18} \mathrm{O}$ signal is buffered by the mixing time of the ocean and the time it takes the major continental ice sheets to form.

For $U_{37}^{k}$ to become a useful stratigraphic tool, the effect of diagenesis upon the signal preserved in sediments must be evaluated. Most paleoceanographers accept that the onset and cessation of ice ages is a cyclic process oscillating around some mean value. Consequently, any parameter recording this process should also have the same properties. Although we do not have a sufficient sampling density to determine the cyclicity of the $U_{37}^{k}$ curve (e.g., Brassell et al., 1986a; Brereton, 1987), a regression line was fitted to the curve, the gradient of which was $5.68 \times 10^{-5} \mathrm{U}_{37}^{\mathrm{k}}$ units/k.y. Hence, over the $575 \mathrm{k} . \mathrm{y}$. studied here, the mean of our curve shifted by only $0.033 \mathrm{U}_{37}^{\mathrm{k}}$ units. In comparison with the range of determined $U_{37}^{k}$ values $(0.821-0.597=0.224)$, this value is small indeed, as well as close to our estimated experimental error (95\% confidence limits $= \pm 0.012, n=8)$. This observation strongly suggests that in this core diagenesis did not effect the ratio of di- to tri-unsaturated alkenones during the first 575 k.y. A similar result has been reported by Brassell et al. (1986b). Furthermore, the results of Volkman et al. (1980) suggest that the alkenone signal should be preserved during transit of the organic debris through the water column.

\section{Assignment of Approximate Isotopic Stages to the Upper $6 \mathrm{~m}$ of Hole $660 \mathrm{~A}$}

The average sedimentation rate for the upper $20 \mathrm{~m}$ of Hole $660 \mathrm{~A}$ has been estimated to be $25 \mathrm{~m} / \mathrm{m}$.y. (Ruddiman, Sarnthein, et al., 1988). We have estimated a separate sedimentation rate for the upper $6 \mathrm{~m}$ of this core on the basis of the molecular stratigraphic data. While the $U_{37}^{k}$ profile of Hole $660 \mathrm{~A}$ does not show an immediately recognizable glacial/interglacial record, it does show systematic variation.

Hole $660 \mathrm{~A}$ ( $4327 \mathrm{~m}$ water depth) lies close to a site previously studied (M16415-2) in $3851 \mathrm{~m}$ of water (Brassell et al., 1986a, 1986b). The record at M16415-2 showed a higher concentration of biomarkers, particularly dinosterol, during the cold stages, an observation thought to be due to an increased primary production of the photic zone in response to intensified paleocirculation (Sarnthein et al., 1981, 1982). In addition, partial oxidation of this organic matter increases the corrosiveness of bottom waters, thus intensifying carbonate dissolution (Sarnthein, 1984) and concentrating the other sedimentary components, including biomarkers. 


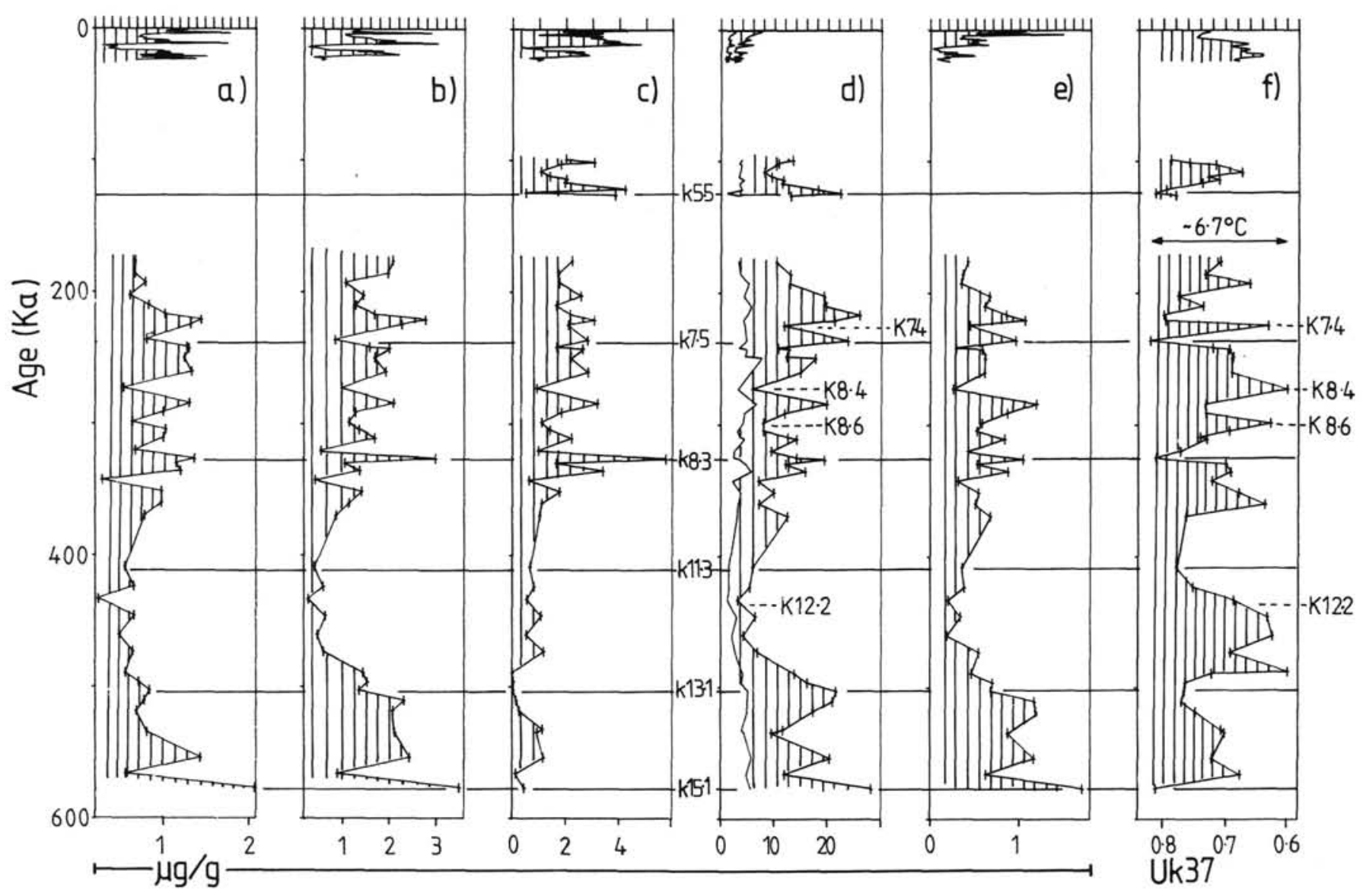

Figure 4. Downhole profiles in Hole $658 \mathrm{~A}$ of the $\mathrm{U}_{37}^{k}$ index and selected compound abundances (in $\mu \mathrm{g} / \mathrm{g}$ dry sediment), as follows: $\mathrm{A} . \mathrm{C}_{29}+\mathrm{C}_{31}$ $n$-alkanes. B. $\mathrm{C}_{28}+\mathrm{C}_{30} n$-alkanols. C. $\mathrm{C}_{30}+\mathrm{C}_{32}$ alkan-1,15-diols. D. C37:3Me + C38:3Me + C 38:3Et $+\mathrm{C} 37: 2 \mathrm{Me}$ ester (low abundance curve) and C37:2Me $+\mathrm{C} 38: 2 \mathrm{Me}+\mathrm{C} 38: 2 \mathrm{Et}$ (high abundance curve). E. Dinosterol. F. U $\mathrm{U}_{37}^{\mathrm{k}}$ index (calculated from Eq. 1, this chapter). The approximate temperature range is calculated from the calibration work of Prahl and Wakeham (1987). Events labeled " $\mathrm{K}$ " have been assigned by comparison with the stacked $\delta^{18} \mathrm{O}$ record of Imbrie et al. (1984). Actual data points are shown for data spanning 180-575 k.y., but they are not included for the first $24 \mathrm{k} . \mathrm{y}$. due to the high sampling intensity (ca. $800 \mathrm{yr}$ ).

On the basis of biomarker abundances, we have tentatively assigned the positions of the glacial extremes $\mathrm{K} 5.5$ and $\mathrm{K} 7.1$ (Fig. 5). In the absence of any strict molecular chronology, we have applied the ages of equivalent $\delta^{18} \mathrm{O}$ events (Imbrie et al., 1984), thus arriving at a sedimentation rate of $22 \mathrm{~m} / \mathrm{m} . \mathrm{y}$. for the upper $6 \mathrm{~m}$ of Hole $660 \mathrm{~A}$.

\section{Comparison of the Downhole Abundances of the \\ Molecular Biomarkers in Holes 658A and 660A}

A comparison of typical gas chromatographic traces of total lipid extracts from Holes 658A and 660A (Fig. 1) reveals that there is a greater relative proportion of marine lipids in sediments from Hole 658A. Furthermore, Figures 4 and 5 show that, although each site contains approximately the same concentration of higher plant $\mathrm{C}_{29}$ and $\mathrm{C}_{31} n$-alkanes $(0.5-3.0 \mu \mathrm{g} / \mathrm{g}$ dry sediment), samples from Hole $658 \mathrm{~A}$ contain higher concentrations $(5-25 \mu \mathrm{g} / \mathrm{g})$ of the seven principal alkenones than those from Hole $660 \mathrm{~A}(1-6 \mu \mathrm{g} / \mathrm{g})$. One can use these concentrations to estimate the flux of biomarker incorporation into the sedimentary column using the dry sediment bulk density and the estimated sedimentation rates.

The ranges of sediment densities for Holes $658 \mathrm{~A}$ and $660 \mathrm{~A}$ are $0.5-1.0$ and $0.42-0.54$, respectively, for the sections of core considered (Ruddiman, Sarnthein, et al., 1988); we use the median values in our approximation. The sedi- mentation rates used are $147 \mathrm{~m} / \mathrm{m}$.y. for Hole 658A (Ruddiman, Sarnthein, et al., 1988) and $22 \mathrm{~m} / \mathrm{m}$.y. for Hole $660 \mathrm{~A}$ (see preceding section). The fluxes thus calculated (Table 1) reflect the different oceanographic settings of the two sites. The higher lipid fluxes at Site 658 are the result of a combination of greater organic supply and enhanced preservation in the oxygen-minimum layer in this area. Certainly, the higher flux of land plant $n$-alkanes is consistent with the proximity of Site 658 A to the land (Sarnthein et al., 1982). The higher flux of dinosterol (from dinoflagellates), and the greatly increased flux of the prymnesiophyte-derived alkenones, is due to the stable upwelling center overlying Site 658.

\section{Comparison of Molecular Abundances in Holes 658A and 660A with Climatic Change}

The link between the abundance of organic biomarkers and changes in the Earth's climate has been discussed briefly in an earlier section. At Hole $660 \mathrm{~A}$, we can see the expected increase in biomarker abundances during glacial stages, particularly in the dinosterol profile (Fig. 5). In contrast, we note the opposite trend at Hole $658 \mathrm{~A}$, particularly in the sections from 100 to $320 \mathrm{k} . y$. and from 420 to 575 k.y. (Fig. 4). While this observation invites speculation, additional information is required before any conclusions can be drawn. 


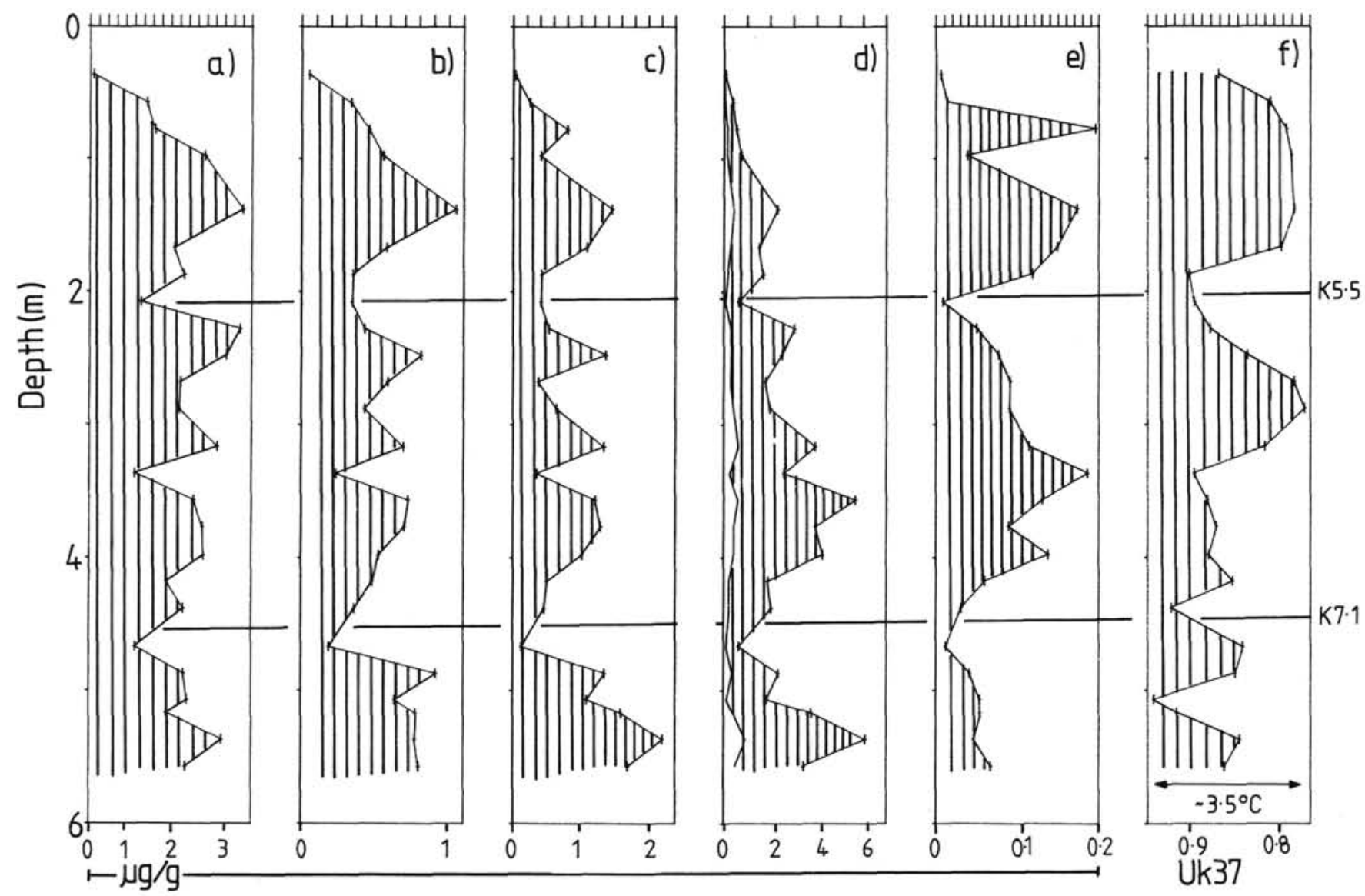

Figure 5. Downhole profiles in Hole $660 \mathrm{~A}$ of the $\mathrm{U}_{37}^{k}$ index and selected compound abundances (in $\mu \mathrm{g} / \mathrm{g}$ dry sediment), as follows: $\mathrm{A}$. $\mathrm{C}_{29}+$ $\mathrm{C}_{31}$ n-alkanes. B. $\mathrm{C}_{28}+\mathrm{C}_{30}$ n-alkanols. C. $\mathrm{C}_{30}+\mathrm{C}_{32}$ alkan-1,15-diols. D. C37:3Me $+\mathrm{C} 38: 3 \mathrm{Me}+\mathrm{C} 38: 3 \mathrm{Et}+\mathrm{C} 37: 2 \mathrm{Me}$ ester (low abundance curve) and C37:2 Me + C38:2Me + C38:2Et (high abundance curve). E. Dinosterol. F. U $\mathrm{U}_{37}^{\mathrm{k}}$ index (calculated from Eq. 1, this chapter). The approximate temperature range is calculated from the calibration work of Prahl and Wakeham (1987). Events K5.5 and K7.1 have been tentatively assigned by comparison with the stacked $\delta^{18} \mathrm{O}$ record of Imbrie et al. (1984).

\section{Downhole Diagenesis of Organic Biomarkers: Hole 658A}

In order to use the abundance of a biomarker in a sediment to assess quantitatively the input to the organic matter from a class of organisms, we must understand the behavior of that compound during transit from the organism to the sediment (e.g., Gagosian et al., 1982) and during sediment burial (e.g., Mackenzie et al., 1982). We address only the latter in this work since we are considering the distribution of these lipids within a sediment core.

Although the onset and cessation of ice age conditions has produced fluctuations in the input of biological marker compounds to the sediment sequence, if we assume that there has been no long-term change in the paleoenvironmental conditions at Site 658 , then we would expect the average concentration of each biomarker to be approximately constant through time. While this appears to hold for most of the biomarkers considered in this work, the alkan-1,15-diols show an overall decrease in abundance, inferring that they may be diagenetically altered or are becoming incorporated into the bound organic fraction.

A further consideration is that compounds from the same biological source, but possessing different chemical structures (e.g., $n$-alkanols and $n$-alkanes; C37:2Me and C37:3Me alkenones), are unlikely to be diagenetically altered at the same rate. Hence, if two such compounds from a common source display a constant average ratio with depth, then it may imply that they are not being altered during diagenesis. This has been demonstrated for the alkenones (see earlier section). However, in the case of the higher plant lipids, the alkanols are enriched by 0.23 alcohol/alkane units downhole (Fig. 4), inferring that the $n$-alkanes are being preferentially altered or are becoming incorporated into the bound organic fraction. This is surprising since we may expect the $n$-alkanol with its functional group to be diagenetically altered at a faster rate than the n-alkane. A more likely explanation is that the relative supply of the two compound classes changed, possibly through a change in the relative amounts of fluvial and eolian inputs.

\section{CONCLUSION}

From the present study we can draw the following conclusions:

1. Lipid flux rates (from marine and terrestrial sources) are higher by a factor of 6 or greater at Hole 658A than at Hole $660 \mathrm{~A}$. This is the combined result of the prominent upwelling above Site 658 and the proximity to shore.

2. The $U_{37}^{k}$ profile, reflecting the sea-surface temperature history at Site 658 , closely resembles an average $\delta^{18} \mathrm{O}$ profile for low-latitude areas. The $U_{37}^{k}$ index is shown to document glacial/interglacial cycles during the last $575 \mathrm{k} . \mathrm{y}$. 


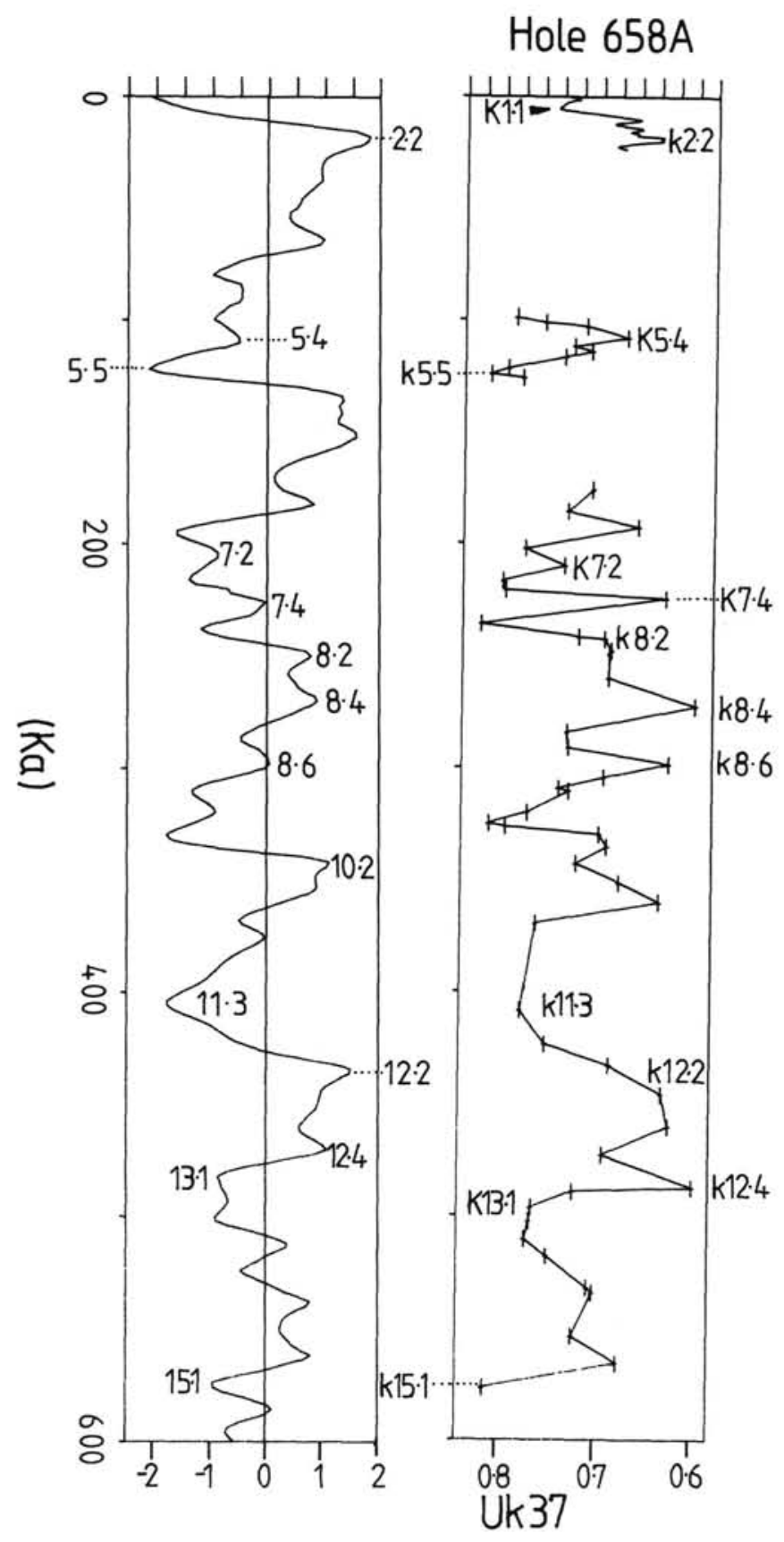

Figure 6. The $U_{37}^{k}$ profile for Hole 658A plotted beside a composite oxygen isotope record comprising the stacked profiles from five low-latitude cores (Imbrie et al., 1984). The parallelism between the two records is apparent. The scale on the stacked oxygen isotope curve does not represent actual $\delta^{18} \mathrm{O}$ values since the data were standardized prior to stacking.

3. There appears to have been no diagenetic imprint on the $\mathrm{U}_{37}^{\mathrm{k}}$ index (measured using the di- and tri-unsaturated compounds) during the $575-\mathrm{k} . \mathrm{y}$. record at Site 658 . However, evidence suggests that the tetra-unsaturated compound, observed in low abundance in the upper parts of the hole, may be lost with sediment burial.

4. The molecular stratigraphic approach has been used to derive an average sedimentation rate of $22 \mathrm{~m} / \mathrm{m}$.y. for the upper $6 \mathrm{~m}$ of Hole $660 \mathrm{~A}$.
Table 1. The estimated flux ranges (expressed as $\mu \mathrm{g} \mathrm{cm}^{-2} \mathrm{k} . \mathrm{y} .^{-1}$ ) for the incorporation of some key organic biomarkers into the sedimentary record at Holes $658 \mathrm{~A}$ and $660 \mathrm{~A}$.

\begin{tabular}{lcc}
\hline & Hole 658A & Hole 660A \\
\hline Dinosterol & $6-12$ & $0-2$ \\
Alkenones & $60-300$ & $2-12$ \\
$n$-Alkanes & $6-33$ & $1-6$ \\
\hline Note: The sums used were as follows: \\
alkenones $=\mathrm{C} 37: 2 \mathrm{Me}+\mathrm{C} 37: 3 \mathrm{Me}+$ \\
C38:3Et $+\mathrm{C} 38: 3 \mathrm{Me}+\mathrm{C} 38: 2 \mathrm{Et}+$ \\
C38:2Me $+\mathrm{C} 39: 2 \mathrm{Et}+\mathrm{C} 37: 2 \mathrm{Me}$ es- \\
ter; and $n$-alkanes $=\mathrm{C}_{29}+\mathrm{C}_{31}$.
\end{tabular}

\section{ACKNOWLEDGMENTS}

We thank the NERC for GC-MS facilities (GR3/2951 and GR3/3758) and for grants supporting molecular stratigraphy (GR3/5957 and GR3/02/247). We would also like to thank P. W. Yendle for helpful discussions concerning the use of principal components analysis.

\section{REFERENCES}

Berger, W. H., Killigley, J. S., Metzler, C. V., and Vincent, E., 1985. Two-step deglaciation: ${ }^{14} \mathrm{C}$-dated high-resolution $\delta^{18} \mathrm{O}$ records from the tropical Atlantic Ocean. Quat. Res. NY, 23:258-271.

Bligh, E. G., and Dyer, W. J., 1959. A rapid method of total lipid extraction and purification. Can. J. Biochem. Physiol., 37: 911917.

Boon, J. J., Rijpstra, W.I.C., de Lange, F., de Leeuw, J. W., Yoshioka, M., and Shimizu, Y., 1979. Black sea sterol-a molecular fossil for dinoflagellate blooms. Nature, 277:125-127.

Brassell, S. C., Brereton, R. G., Eglinton, G., Grimalt, J., Liebezeit, G., Marlowe, I. T., Pflaumann, U., and Sarnthein, M., 1986a. Palaeoclimatic signals recognized by chemometric treatment of molecular stratigraphic data. In Leythaeuser, D., and Rullkötter, J. (Eds.), Advances in Organic Geochemistry, 1985: Oxford (Pergamon Press), 649-660.

Brassell, S. C., Comet, P. A., Eglinton, G., Isaacson, P. J., McEvoy, J., Maxwell, J. R., Thomson, I. D., Tibbetts, P.J.C., and Volkman, J. K., 1980. Preliminary lipid analyses of Sections 440A-7-6, 440B-3-5, 440B-8-4, 440B-68-2, and 436-11-4: Legs 56 and 57, Deep Sea Drilling Project. In Scientific Party, Init. Repts. DSDP, 56, 57, Pt. 2: Washington (U.S. Govt. Printing Office), 1367-1390.

Brassell, S. C., Eglinton, G., Marlowe, I. T., Pflaumann, U., and Sarnthein, M., 1986b. Molecular stratigraphy: a new tool for climatic assessment. Nature, 320:129-133.

Brereton, R. G., 1987. Spectral analysis of multivariate geochemical time series. Chemometrics Intelligent Lab. Sys., 2:177-185.

Dansgaard, W., and Tauber, H., 1969. Glacier oxygen-18 content and Pleistocene ocean temperatures. Science, 166:499-502.

Davis, J. C., 1973. Statistics and Data Analysis in Geology: Chichester (Wiley).

Eglinton, G., and Calvin, M., 1967. Chemical fossils. Sci. Am., 216:32-43.

Eglinton, G., and Hamilton, R. J., 1963. The distribution of alkanes. In Swain, T. (Ed.), Chemical Plant Taxonomy: New York (Academic Press), 187-208.

Eglinton, G., Hamilton, R. J., Raphael, R. A., and Gonzalez, A. G., 1962. Hydrocarbon constituents of the wax coatings of plant leaves: a taxonomic survey. Nature, 193:739-742.

Gagosian, R. B., Smith, S. O., and Nigrelli, G. E., 1982. Vertical transport of steroid alcohols and ketones measured in a sediment trap experiment in the equatorial Atlantic Ocean. Geochim. Cosmochim. Acta, 46:1163-1172.

Imbrie, J., Hays, J. D., Martinson, D. G., McIntyre, A., Mix, A. C., Morley, J. J., Pisias, N. G., Prell, W. L., and Shackleton, N. J., 1984. The orbital theory of Pleistocene climate: support from a 
revised chronology of the marine $\delta^{18} \mathrm{O}$ record. In Berger, A. L., Imbrie, J., Hays, J., Kukla, G., and Saltzman, B. (Eds.), Milankovitch and Climate (Pt. 1): Hingham, MA (D. Reidel), 265-305.

Kolattukudy, P. E., 1976. Chemistry and Biochemistry of Natural Waxes: Amsterdam (Elsevier).

Mackenzie, A. S., Brassell, S. C., Eglinton, G., and Maxwell, J. R., 1982. Chemical fossils-the geological fate of steroids. Science, 217:491-504.

Marlowe, I. T., 1984. Lipids as palaeoclimatic indicators [Ph.D. thesis]. Univ. Bristol, United Kingdom.

Marlowe, I. T., Brassell, S. C., Eglinton, G., and Green, J. C., 1984. Long-chain unsaturated ketones and esters in living algae and marine sediments. In Schenck, P. A., de Leeuw, J. W., and Lijmbach, G.W.M. (Eds.), Advances in Organic Geochemistry, 1983: Oxford (Pergamon Press), 135-141.

McIntyre, A., Kipp, N. G., Bé, A.W.H., Crowley, T., Kellogg, T., Gardner, J. V., Prell, W., and Ruddiman, W. F., 1976. Glacial North Atlantic 18,000 years ago: a CLIMAP reconstruction. In Cline, R. M., and Hays, J. D. (Eds.), Investigation of Late Quaternary Paleoceanography and Paleoclimatology. Mem. Geol. Soc. Am., 145:43-76.

Morris, R. J., and Brassell, S. C., 1988. Long-chain alkanediols: biological markers for cyanobacterial contributions to sediments. Lipids, 23:256-258.

Poynter, J. G., Farrimond, P., Robinson, N., and Eglinton, G., 1989. Aeolian-derived higher plant lipids in the marine sedimentary record: links with paleoclimate. In Leinen, M., and Sarnthein, M., Paleoclimatology and Paleometeorology: Modern and Past Patterns of Global Atmospheric Transport. NATO ASI Series, Ser. D.

Prahl, F. G., and Wakeham, S. G., 1987. Calibration of unsaturation patterns in long-chain ketone compositions for paleotemperature assessment. Nature, 320:367-369.

Prell, W. L., Imbrie, J., Martinson, D. G., Morley, J. J., Nicklas, G., Pisias, N. G., Shackleton, N. J., and Streeter, H. F., 1986. Graphic correlation of oxygen isotope stratigraphy application to the late Quaternary. Paleoceanography, 1:137-162.
Rechka, J. A., and Maxwell, J. R., 1988. Unusual long-chain ketones of algal origin. Tetrahedron Lett., 21:2599-2600.

Ruddiman, W., Sarnthein, M., et al., 1988. Proc. ODP, Init. Repts., 108: College Station, TX (Ocean Drilling Program).

Sarnthein, M., Erlenkeuser, H., von Grafenstein, R., and Schröder, C., 1984. Stable-isotope stratigraphy for the last 750,000 years: "Meteor" core 13519 from the eastern equatorial Atlantic. Meteor Forschungsergeb., Reihe C, 38:9-24.

Sarnthein, M., Tetzlaff, G., Koopmann, B., Wolter, K., and Pflaumann, U., 1981. Glacial and interglacial wind regimes over the eastern subtropical Atlantic and northwest Africa. Nature, 293: 193-196.

Sarnthein, M., Thiede, J., Pflaumann, U., Erlenkeuser, H., Fütterer, D., Koopmann, B., Lange, H., and Seibold, E., 1982. Atmospheric and oceanic circulation patterns off northwest Africa during the past 25 million years. In von Rad, U., Hinz, K., Sarnthein, M., and Seibold, E. (Eds.), Geology of the Northwest African Continental Margin: Berlin Heidelberg-New York (Springer-Verlag), 545-603.

Simoneit, B.R.T., and Eglinton, G., 1977. Organic matter of eolian dust and its input to marine sediments. In Campos, R., and Goñi, J. (Eds.), Advances in Organic Geochemistry, 1975: Oxford (Pergamon Press), 415-430.

Simoneit, B.R.T., Chester, R., and Eglinton, G., 1977. Biogenic lipids in particulates from the lower atmosphere over the eastern Atlantic. Nature, 267:682-685.

Volkman, J. K., Eglinton, G., Corner, E.D.S., and Sargent, J. R., 1980. Novel unsaturated straight-chain $\mathrm{C}_{3}-\mathrm{C}_{39}$ methyl and ethyl ketones in marine sediments and a coccolithophore Emiliania huxleyi. In Douglas, A. G., and Maxwell, J. R. (Eds.), Advances in Organic Geochemistry, 1979: Oxford (Pergamon Press), 219-227.

Date of initial receipt: 8 February 1988

Date of acceptance: 13 October 1988

Ms 108B-161 